\title{
Does financing constraints impact the Chinese companies' pollutants emissions? Evidence from a sample Selection Bias Corrected Model Based on Chinese Company-level Panel Data
}

\author{
Xiaoguang Zhou ( $\boldsymbol{D}$ xiaoguang@ustb.edu.cn ) \\ University of Science and Technology Beijing https://orcid.org/0000-0002-2405-3460 \\ Xinmeng Tang \\ University of Science and Technology Beijing
}

\section{Research Article}

Keywords: financing constraints, pollutant emission, sample selection bias corrected model, Chinese company

Posted Date: August 23rd, 2021

DOl: https://doi.org/10.21203/rs.3.rs-697944/v1

License: (c) (1) This work is licensed under a Creative Commons Attribution 4.0 International License. Read Full License

Version of Record: A version of this preprint was published at Environmental Science and Pollution Research on February 5th, 2022. See the published version at https://doi.org/10.1007/s11356-02218907-7. 


\title{
Does financing constraints impact the Chinese companies' pollutants emissions? Evidence from a sample selection bias corrected model based on Chinese company-level panel data
}

\author{
Xiaoguang Zhou*, Xinmeng Tang \\ School of Economics and Management, University of Science and Technology Beijing, Beijing \\ 100083, China
}

*Correspondence author: xiaoguang@ustb.edu.cn (X. Zhou);

Address: 30 Xueyuan Road, Haidian District, Beijing, China, zip code 100083,

Tel: 86-13691483603, Fax: 86-10-62334132.

E-mail address: tangxinmeng0105@163.com (X. Tang).

Funding: This work was supported by "the National Natural Science Foundation of China (No. 71771023)".

Ethics approval and consent to participate: Not applicable.

Consent for publication: Not applicable.

Competing interests: The authors declare no competing interests.

Data Availability Statement: The datasets used and/or analyzed during the current study are available from the corresponding author on reasonable request.

Authors Contributions: XZ provided the methodology and reviewed the manuscript. XT analyzed and interpreted the data. 


\section{Highlights:}

- The impact of financing constraints on the Chinese companies' pollutants emissions is analyzed.

- A model is constructed to correct the problem of sample selection bias.

- The industry character and ownership heterogeneity are discussed.

- The heterogeneity alleviating effects of financing channel are researched. 


\title{
Does financing constraints impact the Chinese companies' pollutants emissions? Evidence from a sample selection bias corrected model based on Chinese company-level panel data
}

\begin{abstract}
Most Chinese companies face financing constraints and thus lack sufficient funding for operations and investments that would better control their pollutant emissions. A sample selection bias corrected model is constructed to study the impact of financing constraints on the Chinese companies' pollutant emissions using company-level emissions data. The empirical results revealed that financing constraints increase the pollutant emissions of the Chinese companies, including the emissions of industrial wastewater, industrial solid waste and sulfur dioxide. The heterogeneity analysis showed that the impacts of financing constraints on the pollutant emissions of companies operating in highly polluting industries and non-state-owned companies are more significant. And compared with internal financing, bank financing can better mitigate the impact of financing constraints on pollutant emissions through green loan projects. The results are stable after controlling for other important company factors and testing the robustness using the subdivided regression. Several political implications are drawn based on these findings that can help control the pollutant emissions of Chinese companies from the perspective of financing constraints.
\end{abstract}

Key words: financing constraints; pollutant emission; sample selection bias corrected model; Chinese company

\section{Introduction}

China is undergoing a rapid and extensive economic expansion historically unmatched by any other country. However, this miracle of rapid economic development has also made China the world's largest pollutant emitter. Compared with companies in other countries around the world, Chinese companies lack the ability to effectively control pollutant emissions (Jiang et al., 2014). The capital markets and financial systems of developing countries such as China are often labeled as "underdeveloped" in comparison with those of developed countries (Huang and Ji, 2017). Almost all companies in China face varying degrees of financing constraints, meaning that enterprises cannot obtain adequate financing resources (Zhang et al., 2019), needed to fund operations and investments that would reduce the company's pollutant emissions. Therefore, it will be an attractive research on financing constraints that affect the pollutants emissions of enterprises in developing countries.

As the deterioration of environmental conditions in China has caused widespread public concern, the research on the company environmental behavior (CEB) has progressively deepened (Wu et al., 2017; He et al., 2018; Cai et al., 2020). Some scholars have also paid attention to the impact of financing constraints on the CEB. Although taking environmental responsibility will positively influence the company's performance sooner or later ( $\mathrm{Li}$ et al., 2017; Song et al., 2017), other expenditures on corporate social responsibility "crowd out" environmental expenditures (Fullerton and Kim, 2008). Financing constraints thus affect companies' environmental investments as the total costs should be lower than the investment budget (Higgins et al., 2008; Hoberg and Maksimovic, 2015). Therefore, the decisions on corporate environmental responsibility typically involve the allocation of limited financial resources among a series of pollutant treatment projects to minimize the total loss, including penal and vacancy loss (Yu et al., 2016). Andersen (2015) constructed a general equilibrium model to analyze the impact of credit constraints on production-generated pollution emissions, the scale of production, the number of manufacturing companies and the share of companies implementing technology upgrades, finding that the net impact of credit constraints on pollution emissions is positively significant. Subsequently, Andersen (2017) constructed a theoretical model to argue that credit constraints affect asset composition, as these constraints lead to excessive investment in tangible assets, thereby increasing the emission intensity. From the perspective of empirical analysis, merely two studies can be used as indirect evidence that financing constraints affect pollutant emissions. Tian and Lin (2019) conducted a study finding that financing constraints undermine company environmental performance (assessed by whether a company obtained ISO14000 series certification). The more serious the financing constraints, the higher the probability of poor environmental performance. Zhang et al. (2019) demonstrated that 
financing constraints have a significant negative effect on companies' efforts to reduce emissions. As the degree of financing constraints increases, the investment in gas pollution control decreases.

Existing research on the impact of financing constraints on companies' pollutant emissions mainly focus on theoretical analysis or models construction, whereas empirical studies are still limited and can only provide rather circumstantial evidence, including the impact of financing constraints on whether the company has obtained ISO14000 certification (Tian and Lin, 2019) or the amount of investment in gas pollution control (Zhang et al., 2019). Motivated by this, this paper aims to empirically analyze the impact of financing constraints on pollutant emissions of companies in China, one of the developing markets with both the most severe financing constraints and pollution issues.

The data on pollutant emissions of Chinese companies are obtained, whereas the financing constraints of Chinese companies are measured using the investment-cash flow sensitivity (ICFS) index. As voluntary disclosure of pollutant emissions could cause a potential sample selection bias (Heckman, 1979), this paper constructs a sample selection bias corrected model to conduct the regression analysis of financing constraints' impact on pollutant emissions. This paper also controls for the effects of company size, quadratic term of company size, company age, return on equity and company location. Moreover, given that China is still an underdeveloped capital market, an analysis of the different types of companies is needed to identify the companies that the policy should support to maximize the improvement in environmental performance. Therefore, this paper explores how the industry in which a company operates, the type of a company's ownership and the financing channel influence how companies' pollutant emissions are affected by financing constraints.

The innovations and contributions mainly lie in the following four pints. First, this research is a pioneer to empirically study the impact of financing constraints on pollutants emissions. Chinese companies generally face some degree of financing constraints (Tian and Lin, 2019; Zhang et al., 2019), and a lack of funding hinders the control over pollutant emissions. However, this conjecture has never been empirically proved, existing empirical literature on the company environmental behavior (Tian and Lin, 2019; Zhang et al., 2019) can only be used as circumstantial evidence. Therefore, one of the innovations of this paper is to integrate Chinese companies' financing constraints and pollutant emissions into a unified system to explore the direct impact of financing constraints on pollutant emissions. The results confirmed the role that financing constraints plays in reducing pollutant emissions, the implications of which provide solutions for companies to control pollution emissions from financing perspectives.

Second, this research is the first work to empirically focus on the issue of pollutants emissions at the Chinese company-level. The phenomenon that lacking funds will lead to the increase in pollutions emissions has been widely confirmed at the national and regional level in China (Zhou et al., 2020), however, this phenomenon at the Chines company-level has not been studied in-depth due to the difficulty to obtain data on pollutant emissions at the Chinese company-level. Data on pollutants emissions of industrial wastewater, industrial solid waste and sulfur dioxide are collected at companylevel, which makes it possible to study the Chinese company-level issue of pollutants emissions.

Third, a sample selection bias corrected method is constructed to solve the problem that Chinese companies voluntarily publish pollutants emissions data. This method can not only effectively avoid the uncontrollable effects of unobservable factors such as selective disclosure, but also solve the problem of sample selection bias caused by selective disclosure. In the research field of company environmental behavior, the problems of selective data disclosure are frequently faced, the method constructed in this study can provide solutions for future research.

Fourth, the research on heterogeneity conducted in this paper can offer more appropriate policy suggestions. This paper discusses how the industry in which company operates, the type of a company's ownership and the financing channels influence the impact of financing constraints on pollutant emissions. As most Chinese companies face some financing constraints, it is appropriate to analyze what type of companies the policy should focus on to maximize the improvement in environmental performance. The findings of a heterogeneity analysis can identify the types of companies in which a reduction in financing constraints can lead to the greatest reduction in pollutant emissions. Based on the conclusions of this paper, regulators can formulate a more effective policies aimed at easing companies' financing constraints to achieve the overall target of emission reduction. 
Rest of the paper is organized as follows. Section 2 presents about research sample, variables and data. Section 3 talks sample selection bias corrected model construction method. Results and discussions are shown in Section 4. Section 5 gives conclusions and policy implications.

\section{Sample, variable and data}

\subsection{Sample}

Samples used in the two steps of the sample selection bias corrected method (will be introduced in the next section) are different. In the first step of sample selection bias corrected method (i.e. the model capturing the tendency to disclose emission data), the data of all A-share listed companies in China from 2008 to 2018, excluding ST, ST*, financial industry and missing data companies, are obtained as research samples. Overall, the first step uses the unbalanced panel data of 3017 A-share listed companies from 2008 to 2018.

More importantly, in the second step of sample selection bias corrected method (i.e. the sample selection bias corrected model capturing the impact of financing constraints on pollutant emission), the research sample contains the data on Chinese companies that published pollutant emissions data. Specifically, the data cover the emissions of industrial wastewater, industrial solid waste and sulfur dioxide that were published in annual report, social responsibility reports, sustainable development report, environmental responsibility report or environmental, social and corporate governance (ESG) report between 2008 and 2018. Overall, this step uses the unbalanced panel data of 308 companies from 2008 to 2018 .

\subsection{Chinese companies' pollutant emissions data}

As the disclosure of pollutant emissions is voluntary, pollutant emissions data of Chinese companies are collected as following. First, this paper collects the annual report, social responsibility reports, sustainable development report, environmental responsibility report and ESG report of Chinese A-share listed companies. The annual reports of listed companies can be downloaded from the database of Shanghai Stock Exchange ${ }^{1}$ and Shenzhen Stock Exchange ${ }^{2} .31492$ copies of annual report are collected. Social responsibility report of companies listed on Shanghai stock exchange can be found in the website database of Shanghai Stock Exchange, while the report of companies listed on Shenzhen stock exchange can be supplemented in MQI database ${ }^{3} .12603$ copies of social responsibility report are collected. Sustainable development report, environmental responsibility report and EGS report are collected on JUCHAO database ${ }^{4} .341$ copies of these reports are collected. Second, this paper extracts the pollutant emission data in these obtained reports through text analysis and keyword extraction technology, the keywords are set as typical pollutants, such as industrial wastewater, industrial solid waste, sulfur dioxide emission, etc. Third, the company code is matched with the pollutant emission data through the manual sorting method, and thus the pollutant emissions data of Chinese listed companies between 2008 to 2018 can be obtained. In total, data of 308 companies' emissions of industrial wastewater, industrial solid waste and sulfur dioxide from 2008 to 2018 are obtained.

\subsection{Measurement of financing constraints}

As Fazzari et al. (1987) demonstrated that financing constraints can be measured by the sensitivity of investment to cash flow (ICFS), and Ding et al. (2013) and Zhang et al. (2019) proved that ICFS can be used as a proxy for financing constraints of Chinese companies, this paper follows the methodology introduced by Hovakimian and Hovakimian (2009) to assess the degree of financing constraints the Chinese companies face. The degree of financing constraints is given by the difference between the cash flow weighted time-series average investment in fixed assets and its arithmetic time-series average ratio,

\footnotetext{
http://www.sse.com.cn/disclosure/listedinfo/regular/

http://www.szse.cn/disclosure/listed/fixed/index.html

http://mqi.org.cn/

4 http://www.cninfo.com.cn/new/index
} 
as shown in Eq. (1).

$$
F C_{i}=\sum_{t=1}^{n}\left(\frac{\left(\frac{\text { cash flow }}{\text { assets }}\right)_{i, t}}{\sum_{t=1}^{n}\left(\frac{\text { cash flow }}{\text { assets }}\right)_{i, t}} \times\left(\frac{\text { investment }}{\text { assets }}\right)_{i, t}\right)-\frac{1}{n} \sum_{t=1}^{n}\left(\frac{\text { investment }}{\text { assets }}\right)_{i, t} .
$$

where $F C_{i}$ denotes the financing constraints degree of company $i$, cash flow $w_{i, t}$, investment ind $_{i, t}$ and assets $_{i, t}$ represents the cash flow, investment and total assets of company $i$ in year $t$, respectively.

Descriptions, sources and descriptive statistics of used variables are summarized in Table 1.

\section{Sample selection bias corrected model construction}

Given that the disclosure of pollutant emissions data is voluntary for Chinese companies, these data are more likely to be published by companies with better environmental performance. The research sample may therefore face sample selection bias issues depicted in Figure 1A. When only the companies with disclosed data on pollutant emissions (solid points) are taken into account, the relationship between financing constraints and pollutant emissions can be represented by the red line. However, the real impact of financing constraints on emissions is unlikely to be described by this redline, as a large number of Chinese companies do not release pollutant emissions data. It can be argued that companies with poorer environmental performance are generally less willing to disclose their pollutant emissions data voluntarily. Suppose that the pollutant emissions data (hollow points) of these companies are obtained and are taken into account. Then, the true relationship between financing constraints and pollutant emissions can be described by the green line. As can be seen in Figure 1A, when the analysis considers only the companies with voluntarily disclosed emission data, the impact of financing constraints on pollutant emissions is overestimated.

Heckman (1979) proposed a method for solving the problem of sample selection bias depicted in Figure 1B. The principle of this method is as follows. First, the model capturing the tendency to disclose emission data is constructed. Companies that do not publish information on their pollutant emissions are added to the original sample, and the Probit model is used to calculate the tendency to disclose emissions data under different degrees of financing constraint (i.e. the Inverse Mills Ratio). Then, the sample selection bias corrected model is constructed. The sample points of the companies that publish pollutant emissions data are vertically shifted upwards according to their tendency to disclose emissions data. The smaller the tendency to disclose information, the greater the upward shift. As can be seen in Figure 1B, the original sample points (black solid points) are shifted upwards to the corrected sample points (orange solid points), and the orange line representing the relationship between financing constraints and pollutant emissions is obtained through the OLS method. A comparison of Figures 1A and 1B reveals that the true relationship captured by the orange line in Figure $1 \mathrm{~B}$ is consistent with the theoretical relationship depicted by the green line in Figure 1A. Based on this principle, the regression model is calculated using the following steps.

Pollutant Emission

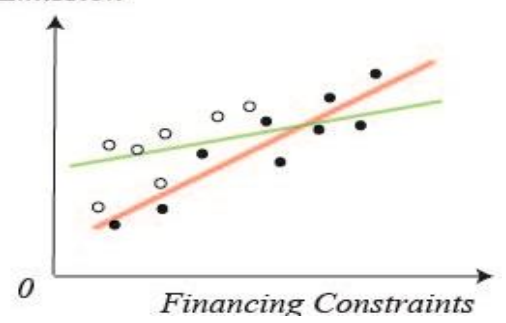

A.

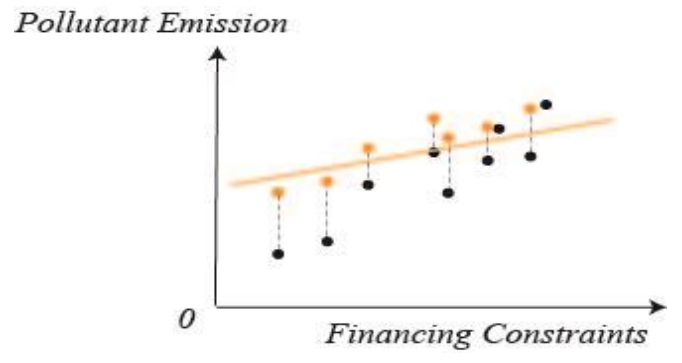

B.

Figure 1.

The construction principle of the sample selection bias corrected model. 
Table 1.

187 Summary of variables description, sources and descriptive statistics.

\begin{tabular}{|c|c|c|c|c|c|c|}
\hline Variables & Abbr. & Description & Sources & Unit & Mean & Std. Dev. \\
\hline \multicolumn{7}{|l|}{ Independent variable: } \\
\hline Financing constraints & $F C_{i}$ & As in Eq. (1) & Wind Database & & 0.07 & 0.04 \\
\hline \multicolumn{7}{|l|}{ Dependent variables: } \\
\hline Industrial wastewater emission & lnwater $_{i, t}$ & $\begin{array}{l}\text { The logarithmic value of company } i \text { 's industrial wastewater emission in } \\
\text { year } t\end{array}$ & $\begin{array}{l}\text { Annual report, social responsibility report, sustainable development } \\
\text { report, environmental responsibility report or ESG report }\end{array}$ & $\operatorname{lnKT}$ & 7.49 & 3.61 \\
\hline Industrial solid waste emission & $\ln$ solid $_{i, t}$ & $\begin{array}{l}\text { The logarithmic value of company } i \text { 's industrial solid waste emission in } \\
\text { year } t\end{array}$ & Ditto & $\operatorname{lnKT}$ & 10.14 & 3.19 \\
\hline Sulfur dioxide emission & $\ln S O_{2 i, t}$ & The logarithmic value of company $i$ 's sulfur dioxide emission in year $t$ & Ditto & $\operatorname{lnKT}$ & 5.68 & 3.05 \\
\hline \multicolumn{7}{|l|}{ Control variables: } \\
\hline Company size & Size $_{i, t}$ & The logarithmic value of company $i$ 's total assets in year $t$ & Wind Database & $\begin{array}{l}\text { lnMillion } \\
\text { yuan }\end{array}$ & 10.34 & 1.64 \\
\hline Company age & $A g e_{i, t}$ & The number of years from the establishment of company $i$ to year $t$ & Wind Database & & 17.31 & 5.79 \\
\hline Return on equity & $\operatorname{Roe}_{i, t}$ & The ratio of return on equity of the company $i$ in year $t$ & Wind Database & $\%$ & 4.89 & 2.01 \\
\hline Company region & Region $_{i}$ & $\begin{array}{c}\text { The dummy variable equal to } 1 \text {, if the company } i \text { is located in central or } \\
\text { eastern China, otherwise equal to } 0\end{array}$ & Wind Database & & 0.59 & 0.49 \\
\hline \multicolumn{7}{|l|}{ Heterogeneity research variables: } \\
\hline Bank financing channel & Bank $_{i, t}$ & The ratio of interest expense to total assets of the company $i$ to year $t$ & Wind Database & $\%$ & 0.18 & 0.17 \\
\hline Internal financing channel & Internal $_{i, t}$ & The ratio of net income to total assets of the company $i$ to year $t$ & Wind Database & $\%$ & 4.28 & 2.86 \\
\hline
\end{tabular}


The original model capturing the impact of financing constraints on pollutant emissions can be expressed as Eq. (2).

$$
\text { In pollutant emisson } \text { ent }_{i}=\hat{\alpha}_{0}+\hat{\alpha}_{1} F C_{i, t}+\hat{\alpha}_{m} X_{i, t}+\varepsilon_{i, t} \text {, }
$$

where lnpollutant emisson ${ }_{i, t}$ denotes the logarithmic value of company $i$ 's pollutant emissions in year $t$, $F C_{i, t}$ is the variable for the financing constraints degree of company $i$ in year $t, X$ represents the matrix of control variables, $\varepsilon$ denotes the residuals, $\varepsilon_{i, \tau} \sim N\left(0, \sigma_{\varepsilon}^{2}\right)$.

Since the disclosure of pollutant emissions data is voluntary, whether variables of pollutant emissions in Eq. (2) can be observed depends on the binary selection variable $Z_{i, t}$, as shown in Eq. (3).

$$
\text { In pollutant emisson }{ }_{i, t}=\left\{\begin{array}{cc}
\text { Observable, } & Z_{i, t}=1 \\
\text { Unobservable, } & Z_{i, t}=0
\end{array},\right.
$$

where the binary selection variable $Z_{i, t}$, is determined by the model as shown in Eqs. (4)-(5).

$$
Z_{i, t}=\left\{\begin{array}{cc}
1, & Z_{i, t}^{*}>0 \\
0, & Z_{i, t}^{*} \leq 0
\end{array},\right.
$$

$$
Z_{i, t}^{*}=\hat{\beta}_{0}+\hat{\beta}_{1} F C_{i, t}+\hat{\beta}_{m} X_{i, t}+\mu_{i, t},
$$

where $Z_{i, t}^{*}$, is an unobservable potential variable. Assume $\mu_{i, \tau} \sim N\left(0, \sigma_{\mu}{ }^{2}\right)$, the model capturing the tendency to disclose emission data is Probit model as in Eq. (6).

$$
\mathrm{P}\left(Z_{i, t}=1 \mid F C_{i, t}, X_{i, t}\right)=\Phi\left(\beta_{0}+\beta_{0} F C_{i, t}+\beta_{m} X_{i, t}\right),
$$

where $\Phi(\cdot)$ denotes standard normal distribution function. The Probit method is used to perform regression, and the sample of this model includes companies both published and didn't publish pollutant emission data. The estimated value of regression coefficient of $\beta$ can be obtained.

According to the model above, the conditional expectation of the sample of the companies that publish pollutant emissions data is as Eq. (7).

$$
\begin{aligned}
& E\left(\ln \text { pollutant emisson } n_{i, t} \mid \text { Observable }\right)=E\left(\ln \text { pollutant emisson }{ }_{i, t} \mid Z_{i, t}^{*}>0\right) \\
& =E\left(\alpha_{0}+\alpha_{1} F C_{i, t}+\alpha_{m} X_{i, t}+\varepsilon_{i, t} \mid \beta_{0}+\beta_{1} F C_{i, t}+\beta_{m} X_{i, t}+\mu_{i, t}>0\right) \\
& =E\left(\alpha_{0}+\alpha_{1} F C_{i, t}+\alpha_{m} X_{i, t}+\varepsilon_{i, t} \mid \mu_{i, t}>-\beta_{0}-\beta_{1} F C_{i, t}-\beta_{m} X_{i, t}\right) \\
& ==\hat{\alpha}_{0}+\hat{\alpha}_{1} F C_{i, t}+\hat{\alpha}_{m} X_{i, t}+E\left(\varepsilon_{i, t} \mid \mu_{i, t}>-\beta_{0}-\beta_{1} F C_{i, t}-\beta_{m} X_{i, t}\right) \text {. }
\end{aligned}
$$

The joint probability density function of random variables $\varepsilon$ and $\mu$ is $f(\varepsilon, \mu)$, and the correlation coefficient is $\rho$. The Eq. (7) thus can be further deformed as shown in Eq. (8).

$$
\begin{aligned}
\text { E(In pollutant emisson } \left.\left.\right|_{i, t} \mid \text { Observable }\right) & =\hat{\alpha}_{0}+\hat{\alpha}_{1} F C_{i, t}+\hat{\alpha}_{m} X_{i, t}+\int_{-\infty}^{+\infty}\left[\varepsilon f_{\varepsilon \mid \mu}\left(\varepsilon \mid \mu \geq-\beta_{0}-\beta_{1} F C-\beta_{m} X\right)\right] d \varepsilon \\
& =\hat{\alpha}_{0}+\hat{\alpha}_{1} F C_{i, t}+\hat{\alpha}_{m} X_{i, t}+\rho \sigma_{\varepsilon} \lambda\left(-\frac{\beta_{0}+\beta_{1} F C_{i, t}+\beta_{m} X_{i, t}}{\sigma_{\mu}}\right),
\end{aligned}
$$

where $\lambda(\cdot)$ denotes the Inverse Mill's Ratio function as in Eq. (9), that is the probability density function of standard normal $\varphi(\mathrm{c})$ divide by the shadow area that larger than $\mathrm{c}$ under the probability density function curve 1- $\Phi(\mathrm{c})$ as shown in Figure 2.

$$
\lambda(\mathrm{c})=\frac{\varphi(\mathrm{c})}{1-\Phi(\mathrm{c})} .
$$

Based on the estimated value of regression coefficient of $\beta$ obtained by performing regression on Eq. (6), the specific calculation method of $I M R$ is shown in Eq. (10), the $I M R$ can be explained as companies' tendency to disclose pollutant emissions data. 


$$
I M R_{i, t}=\lambda\left(-\frac{\hat{\beta}_{0}+\hat{\beta}_{1} F C_{i, t}+\hat{\beta}_{m} X_{i, t}}{\sigma_{\mu}}\right)
$$

The marginal effect of the change of financing constraints on the pollutant emissions is shown in Eq. (11).

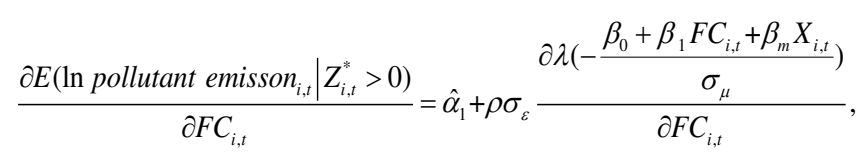

where the first item is the direct effect of financing constraints on the company's pollutant emissions, and the second item is the indirect effect of companies' tendency to disclose pollutant emissions data (i.e. sample selection bias). Thus, it can be seen that the estimation results of $\alpha_{1}$ are biased if directly estimate using Eq. (2).

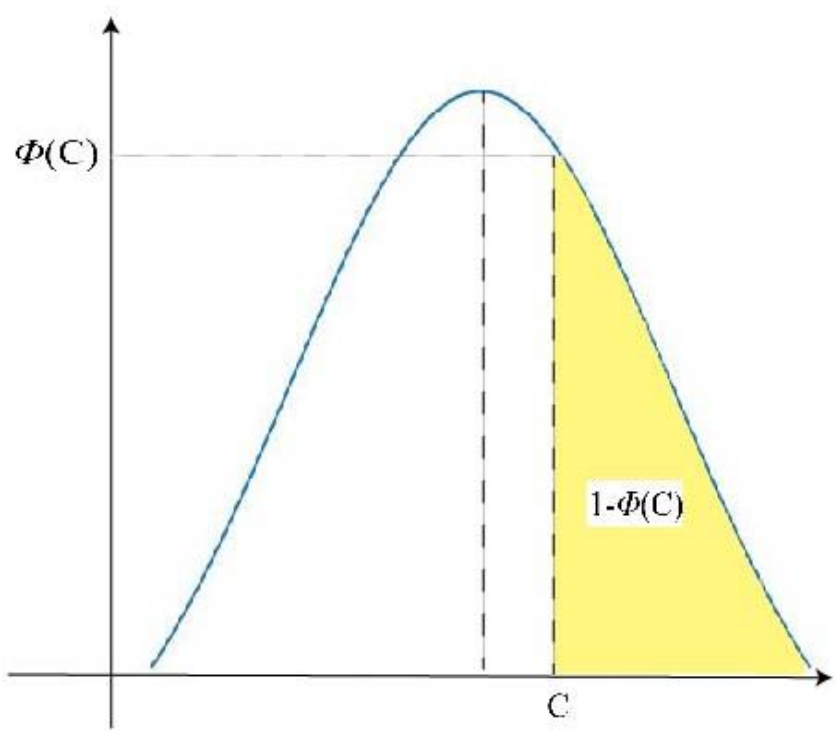

Figure 2.

The Inverse Mill's Ratio.

Based on this, taking $I M R$ into regression analysis as an independent variable, the sample selection bias corrected model capturing the impact of financing constraints on pollutant emissions can be expressed as Eq. (12).

$$
\ln \text { pollutant emisson } \text { en }_{i, t}=\hat{\gamma}_{0}+\hat{\gamma}_{1} F C_{i, t}+\hat{\gamma}_{m} X_{i, t}+\rho \sigma_{\varepsilon} I M R_{i, t}+\eta_{i, t},
$$

where $\eta$ denotes the residuals. Eq. (12) was constructed by adding the IMR that regressed using the Probit method from the Probit model capturing the tendency to disclose emission data (Eq. (6)). That is to say, the unobservable factor affecting the company's pollutant emissions, that is, the company's selective disclosure behavior, is controlled in the Eq. (12), which can effectively solve the problem of sample selection bias faced by the original model (Eq. (2)). Thus, Eq. (12) is taken as the baseline model for regression analysis in the next section.

\section{Results and discussions}

\subsection{Impact of financing constraints on pollutant emissions}

To avoid a spurious regression, the stationarity of variables is firstly tested. The time series diagram of variables shown in Figure 3 reveals that the data have the intercept but not the trend term, therefore the panel data stationarity tests are performed only for the intercept term, and the results are reported in Table 2 . All variables are stationary at I(0) in Table 2 and thus suitable for regression analysis. 

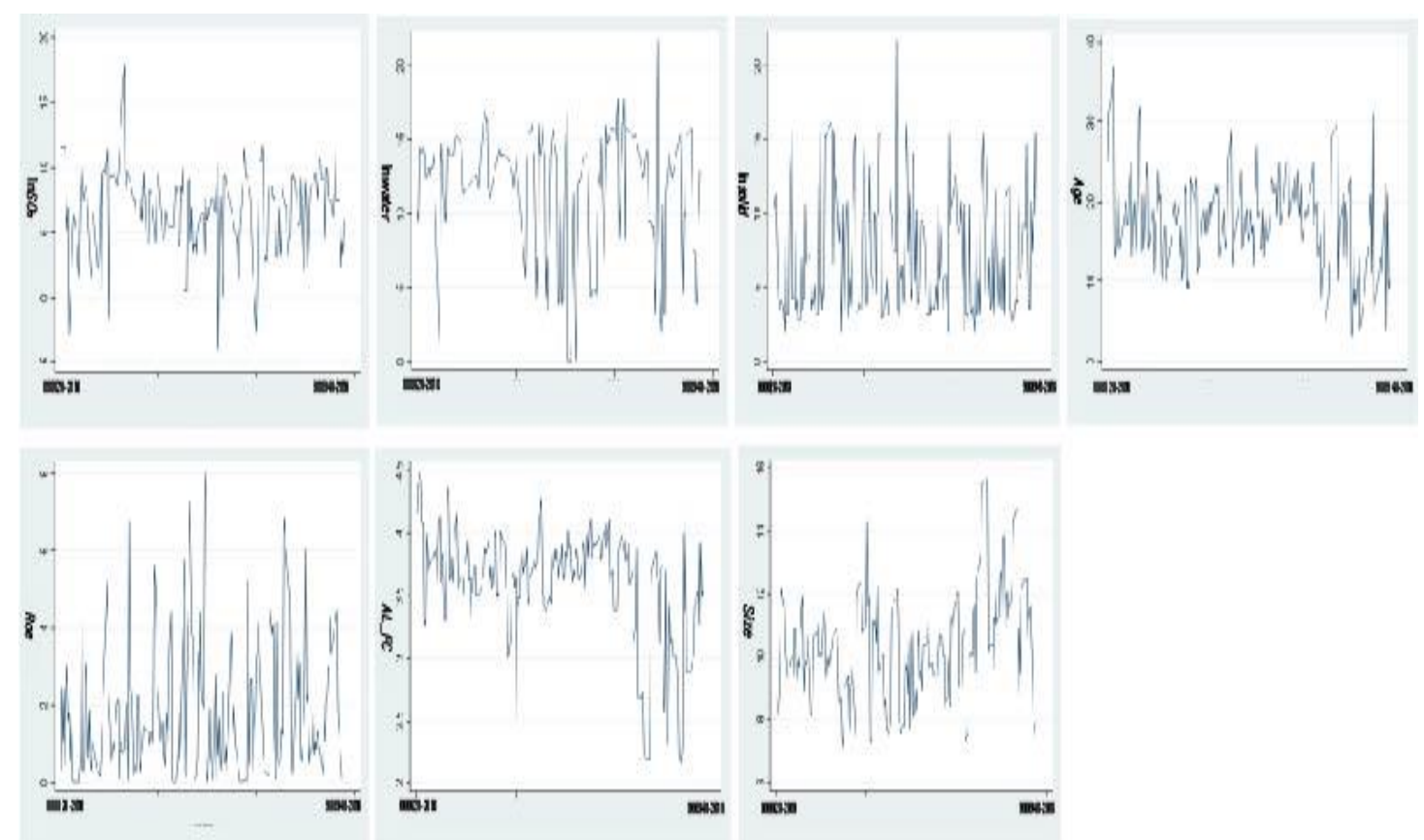

Figure 3.

Time series diagram of variables.

The regression results of the sample selection bias corrected model capturing the impact of financing constraints on pollutant emissions obtained using Eq. (12) are presented in Figure 4. Financing constraints have a significantly positive impact on the companies' pollutant emissions. Specifically, with each $1 \%$ increase in financing constraints, the emissions of industrial wastewater, industrial solid waste and sulfur dioxide increased by an average of $1.44 \%, 2.38 \%$ and $1.16 \%$, respectively. At the $95 \%$ confidence level, these emissions increased by a minimum of $1.04 \%, 2.03 \%$ and $0.82 \%$ respectively, and by a maximum of $1.84 \%, 2.74 \%$ and $1.50 \%$ respectively, with each $1 \%$ increase in financing constraints. The impact of financing constraints on pollutant emissions is relatively larger than those of control variables such as company size and age, suggesting that financially constrained companies are more likely to face greater resistance to reducing pollutant emissions.

Table 2.

Results of stationarity tests (for the intercept term). The Augmented Dickey-Fuller (ADF)-Fisher and Phillips-Perron (PP)-Fisher tests are used for the stationarity test. The symbols *, **, and $* * *$ indicate significance at the $10 \%, 5 \%$, and $1 \%$ levels, respectively.

\begin{tabular}{|c|c|c|c|}
\hline & ADF-Fisher & PP-Fisher & Conclusions \\
\hline lnwater & $14.7017 * *$ & $16.8275^{*}$ & stationary \\
\hline lnsolid & $13.5430 *$ & $17.0756^{* * *}$ & stationary \\
\hline $\ln \mathrm{SO}_{2}$ & $60.9114 * *$ & $61.4684 * *$ & stationary \\
\hline$F C \_A L$ & $39.5736^{* *}$ & $43.4467 * * *$ & stationary \\
\hline Size & $80.2273 * * *$ & $123.794 * * *$ & stationary \\
\hline Age & $29.1224^{*}$ & $34.9408^{* *}$ & stationary \\
\hline Roe & $43.3473 * * *$ & $50.3404 * * *$ & stationary \\
\hline
\end{tabular}

The most obvious explanation for this finding is that companies facing financing difficulties lack sufficient funding for operations and investments that would better control pollutant emissions, such as the replacement of highly polluting equipment or the development of green technologies. Zhang et al. (2019) found that financing constraints have a significant negative impact on Chinese companies' efforts to reduce emissions, as the increase in financing constraints is associated with a decrease in investment in gas pollution control. Zhang et al. (2020) and Yu et al. (2021) confirmed that green innovation would suffer if Chinese companies faced higher financing constraints. 
Variables

\begin{tabular}{|c|c|c|}
\hline & & regression $\mathrm{c}$ \\
\hline$F C$ & & 1.4402 \\
\hline Size & 0.8879 & \\
\hline$S_{i z e^{2}}$ & -0.0295 & \\
\hline Age & 0.0846 & \\
\hline Roe & & 5.6512 \\
\hline Region & & 2,1518 \\
\hline
\end{tabular}

Dependent variable=Insolid

$0.8879(0.3712)$

$-0.0295(-2.2460)^{*}$

$0.0846(2.0374)^{*}$

$5.6512(1.6937)^{*}$

$2.1518(3.6672)^{* * *}$

(1)

$3.5692(0.3078)$

Constant

$2.1843(4.1395)^{* * *}$

$S . E .=2.8568$

Ad. $R^{2}=0.3182$

Prob. $(F$-statistic $)=0.0000$ regression coefficient ( $t$-value)

$2.3835 \quad 2.3835$ (2.2212)**

$5.5827 \quad 5.5827(6.5344)^{* * *}$

$\begin{array}{rl}2.3835 & 2.3835(2.2212)^{* *} \\ 5.5827 & 5.5827(6.5344)^{* * *}\end{array}$

$-0.2625(-6.8433)^{* * *}$

$0.0478(2.6602)^{* *}$

0.0478

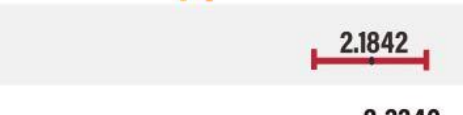

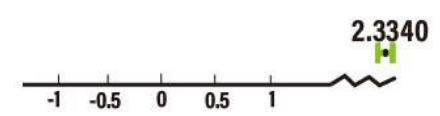

$2.1842(1.6690)^{*}$

$2.3340(4.0562)^{* * *}$

$\begin{array}{llll}-1 & -0.5 & 0 & 0.5\end{array}$
Dependent variable $=\ln \mathrm{SO}_{2}$

\begin{tabular}{ccc}
\hline & \multicolumn{2}{r}{ regression coefficient ( $t$-value) } \\
& 1.1631 & $1.1631(2.1337)^{* *}$ \\
& 2.3301 & $2.3301(2.1111)^{* *}$ \\
0.0745 & & $-0.0745(-2.4169)^{* *}$ \\
0.0893 & & $0.0893(2.8702)^{* *}$ \\
& & $6.39326 .3932(3.2123)^{* * *}$
\end{tabular}

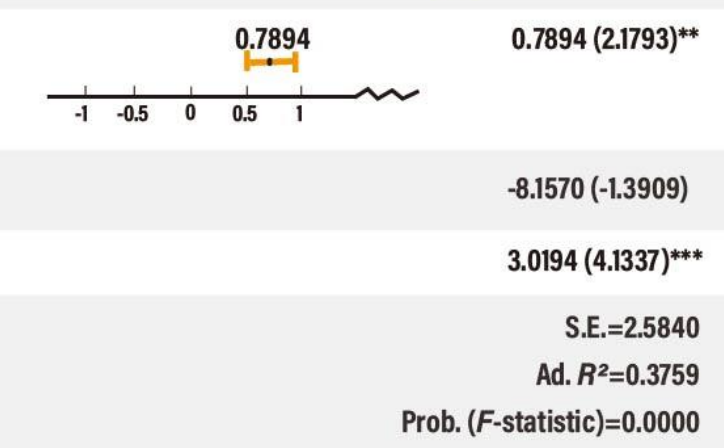

Figure 4.

Results of the sample selection bias corrected model capturing the impact of financing constraints on pollutant emissions. Columns from left to right present the results for the dependent variables of emissions of the industrial wastewater, industrial solid waste and sulfur dioxide, respectively. Solid points denote the size of an independent variable's effect on pollutant emissions, and the green, yellow and red lines represent $99 \%$, $95 \%$ and $90 \%$ confidence interval, respectively. $T$-values are reported in parentheses. The symbols *, **, and $* * *$ indicate significance at the $10 \%, 5 \%$, and $1 \%$ levels, respectively. 
Another possible explanation is offered by the input-output theory. In the context of low-carbon and green development, some consumers choose green products and services. Motivated by profit maximization, companies can strive low-carbon, green products to attract environmentally conscious consumers. However, in the case of stricter financing conditions, companies face higher financial costs, which has a negative impact on green and low-carbon products and limits the degree of emission reduction.

In addition, the excessive investment in tangible assets may also provide a possible explanation for this finding. Financing constraints may distort the company's incentive to overinvest in tangible assets (Andersen, 2017) that can retain greater value in the event of a company's default and thus are favored by lenders (Manova, 2013). Insufficient investment in intangible assets, such as research and development and the implementation of new abatement technology undermine a company's environmental performance.

The results also found the inverted U-shaped relationship between company size and pollutant emissions. The significantly negative regression coefficient of the quadratic term of company size suggests that as the company expands, the company's pollutant emissions first increase and then decrease. The company size has such an effect on the emissions of industrial wastewater, industrial solid waste and sulfur dioxide. This inverted U-shaped relationship indicates the existence of the Environmental Kuznets curve (EKC) at Chinese company-level (Earnhart and Lizal, 2006; Vinayagamoorthi et al., 2016; Zhou et al., 2020). Furthermore, the results suggest that with increasing company age and return on equity, a company's pollutant emissions gradually increase, and companies located in central or eastern China emitted more pollutants than those based in western China.

\subsection{Industry heterogeneity analysis}

Industry heterogeneity is firstly discussed (Table 3). The research sample is divided into the companies from highly and lightly polluting industries according to the "List of Listed Companies' Environmental Protection Inspection Industry Classification Management Directory" issued by the Ministry of Environmental Protection of China.

\section{Table 3.}

Results of the sample selection bias corrected model capturing the impact of financing constraints on pollutant emission of companies operating in different industries. $T$-values are reported in parentheses. The symbols *, **, and *** indicate significance at the $10 \%, 5 \%$, and $1 \%$ levels, respectively.

\begin{tabular}{|c|c|c|c|c|c|c|}
\hline & \multicolumn{3}{|c|}{ Highly Polluting Industry } & \multicolumn{3}{|c|}{ Lightly Polluting Industry } \\
\hline & (1) & $(2)$ & (3) & (4) & $(5)$ & $(6)$ \\
\hline & lnwater & lnsolid & $\ln \mathrm{SO}_{2}$ & lnwater & lnsolid & $\ln \mathrm{SO}_{2}$ \\
\hline \multirow[t]{2}{*}{$F C$} & 24.9711 & 14.2139 & 2.8631 & 0.5762 & 0.1757 & 0.6135 \\
\hline & $(2.6036)^{* *}$ & $(1.8139)^{*}$ & $(2.8664)^{* * *}$ & $(2.0487)^{* *}$ & $(1.7814)^{*}$ & $(2.9781)^{* * *}$ \\
\hline \multirow{2}{*}{ Size } & 2.7225 & 16.153 & 6.5908 & 4.5231 & 10.2886 & 4.7934 \\
\hline & $(1.3927)$ & $(1.0633)$ & $(5.2542)^{* * *}$ & $(1.4660)$ & $(1.6927)^{*}$ & $(1.8731)^{*}$ \\
\hline \multirow{2}{*}{$S i z e^{2}$} & -0.0998 & -0.7556 & -0.2699 & 0.2303 & -0.5112 & -0.2183 \\
\hline & $(-1.0464)$ & $(-2.0121)^{* *}$ & $(-4.4922)^{* * *}$ & $(1.4795)$ & $(-2.5528)^{* *}$ & $(-2.6518)^{* *}$ \\
\hline \multirow{2}{*}{ Age } & -0.0896 & -0.1081 & -0.0838 & 0.0733 & 0.0031 & 0.0876 \\
\hline & $(3.6229) * * *$ & $(-2.5758)^{* *}$ & $(-3.4298)^{* * *}$ & $(1.7492)^{*}$ & $(2.0314)^{* *}$ & $(1.6087)^{*}$ \\
\hline \multirow{2}{*}{ Roe } & -2.6222 & -4.7562 & -3.3318 & 1.0192 & 2.2683 & 2.2716 \\
\hline & $(3.7263)^{* * *}$ & $(-0.7100)$ & $(-1.9615)^{*}$ & $(1.9418)^{*}$ & $(2.0387)^{* *}$ & $(2.6920)^{* *}$ \\
\hline \multirow{2}{*}{ Region } & -0.0602 & -1.4889 & -0.7443 & 4.3539 & 3.5825 & 0.8891 \\
\hline & $(-0.1451)$ & $(-4.6222)^{* * *}$ & $(-2.6543)^{* *}$ & $(6.0850)^{* * *}$ & $(3.4347)^{* * *}$ & $(2.2751)^{* *}$ \\
\hline \multirow{2}{*}{ Constant } & -4.6732 & -69.0291 & -29.4900 & 29.9128 & -43.0931 & -18.0261 \\
\hline & $(-0.4692)$ & $(-0.8998)$ & $(-4.5599) * * *$ & $(1.9907)^{* *}$ & $(-1.6012)^{*}$ & $(-1.4273)$ \\
\hline \multirow{2}{*}{$I M R$} & 4.2214 & 3.7524 & 7.1842 & 4.3153 & 4.1135 & 1.0152 \\
\hline & $(2.3821)^{* *}$ & $(2.9831)^{* * *}$ & $(3.1114)^{* * *}$ & $(1.8997)^{* *}$ & $(1.7991)^{* *}$ & $(3.0013)^{* * *}$ \\
\hline S.E. & 2.2567 & 1.4040 & 1.9050 & 2.8081 & 1.8307 & 3.1835 \\
\hline Ad. $R^{2}$ & 0.5181 & 0.6875 & 0.5246 & 0.4447 & 0.4956 & 0.4816 \\
\hline Prob. ( $F$-statistic $)$ & 0.0000 & 0.0000 & 0.0000 & 0.0000 & 0.0000 & 0.0000 \\
\hline
\end{tabular}

As can be seen from the figure of regression coefficient capturing the impact of financing constraints on pollutant emissions of companies operating in different industries (Figure 5), the impacts of financing constraints on pollutant emissions of companies from highly and lightly polluting industries vary significantly. The coefficients capturing the impact of financing constraints on the emissions of companies operating in highly polluting industries are significantly greater than those representing the 
Specifically, with each $1 \%$ increase in financing constraints, the emissions of industrial wastewater, industrial solid waste and sulfur dioxide produced by the companies operating in highly polluting industries increased by an average of $24.97 \%, 14.21 \%$ and $2.86 \%$ respectively, whereas those produced by the companies from lightly polluting industries increased only by an average of $0.58 \%, 0.18 \%$ and $0.61 \%$ respectively. These findings suggest that, compared with the lightly polluting companies, the highly polluting companies constrained by funding face greater difficulties in taking measures to reduce pollutant emissions.

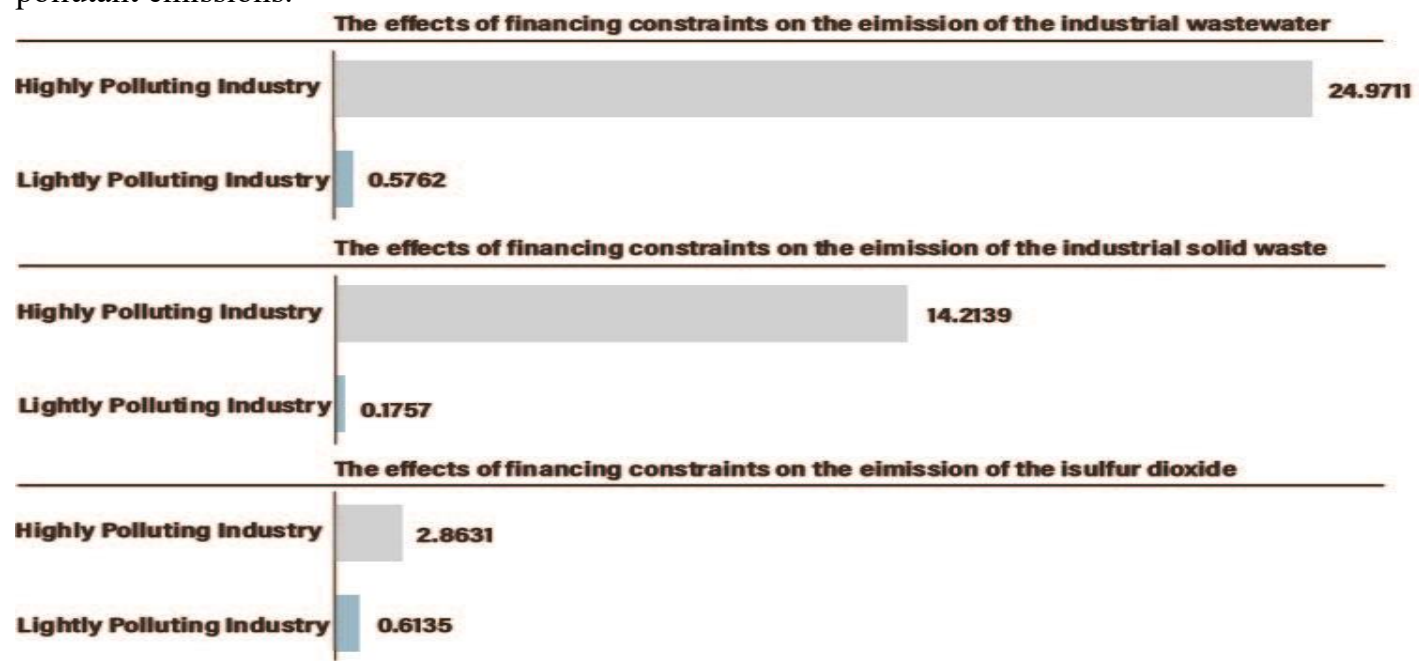

Figure 5.

Regression coefficient capturing the impact of financing constraints on pollutant emissions of companies operating in different industries. Ranks top to bottom present the results for the dependent variables of the emissions of industrial wastewater, industrial solid waste and sulfur dioxide, respectively.

Industry heterogeneity also affects the impact of other factors on companies' emissions. The inverted U-shaped relationship between company size and pollutant emissions varies significantly depending on the nature of the industry in which a company operates. The turning points of EKC are shifted to the right in the case of companies from highly polluting industry. Furthermore, the coefficients of company age and return on equity are significantly negative for the companies operating in highly polluting industries, which differs from the results obtained using the full sample as well as the sample containing only companies from lightly polluting industry. In addition, the results imply that when a company is located in eastern China, then the companies from highly polluting industries emit fewer pollutants than their western China counterparts, whereas the companies from lightly polluting industries emit more pollutants than those based in western China. The possible explanations for these manifestations of industry heterogeneity may lie in the sooner reaching a turning point of EKC or in the stronger regulations of highly polluting companies.

\subsection{Ownership heterogeneity analysis}

Ownership heterogeneity is then discussed (Table 4). The research sample is divided into the state-owned companies, controlled by the State-owned Assets Supervision and Administration Commission (SASAC), and the non-state-owned companies, including private-owned and foreignowned companies.

As can be seen from Table 4, the impacts of financial constraints on pollutant emissions of stateowned and non-state-owned companies vary significantly. Specifically, with each $1 \%$ increase in financing constraints, the emissions of industrial wastewater, industrial solid waste and sulfur dioxide produced by the non-state-owned companies increased by an average of $3.71 \%, 2.11 \%$ and $2.01 \%$ respectively, whereas the pollutant emissions produced by the state-owned companies are not affected by financing situations, as the regression coefficients capturing the impact of financing constraints on such companies' emissions are not significant. The explanation for ownership heterogeneity may be that, compared with non-state-owned companies, state-owned companies generally boast a better reputation and better bank-enterprise relations, and therefore have higher chances of obtaining bank loans (Brandt and Li, 2003; Allen et al., 2005), Chinese state-owned companies thus do not have to consider financing 
constraints when deciding on pollutants emissions.

\section{Table 4.}

Results of the sample selection bias corrected model capturing the impact of financing constraints on pollutant emissions of companies with different types of ownership. $T$-values are reported in parentheses. The symbols ${ }^{*},{ }^{* *}$, and ${ }^{* * *}$ indicate significance at the $10 \%, 5 \%$, and $1 \%$ levels, respectively.

\begin{tabular}{|c|c|c|c|c|c|c|}
\hline & \multicolumn{3}{|c|}{ State-owned } & \multicolumn{3}{|c|}{ Non-state-owned } \\
\hline & (7) & (8) & (9) & (10) & (11) & (12) \\
\hline & $\ln w a t e r$ & lnsolid & $\ln \mathrm{SO}_{2}$ & $\ln w a t e r$ & lnsolid & $\ln \mathrm{SO}_{2}$ \\
\hline \multirow[t]{2}{*}{$F C$} & -0.2556 & 11.4845 & 1.2918 & 3.7130 & 2.1138 & 2.0137 \\
\hline & $(-0.3496)$ & $(0.7012)$ & (1.1298) & $(2.6061)^{* *}$ & $(3.1159) * * *$ & $(2.3104)^{* *}$ \\
\hline \multirow{2}{*}{ Size } & 3.9798 & 19.5495 & -1.2393 & -3.7295 & 4.9028 & 2.0607 \\
\hline & $(1.5958)^{*}$ & $(1.1482)$ & $(-0.4532)$ & $(-0.9101)$ & $(1.9272)^{* *}$ & (1.3206) \\
\hline \multirow{2}{*}{$S i z e^{2}$} & -0.1779 & -0.9126 & 0.0787 & -0.1959 & -0.1846 & -0.0569 \\
\hline & $(-1.6659) *$ & $(-2.0373)^{* * *}$ & $(1.6196)^{*}$ & $(-1.9185)^{* * *}$ & $(-1.6485) *$ & $(-1.7144) *$ \\
\hline \multirow{2}{*}{ Age } & 0.0175 & 0.6150 & 0.1359 & 0.0177 & 0.0169 & 0.0344 \\
\hline & $(2.4566)^{* *}$ & $(5.8130)^{* * *}$ & $(2.9442)^{* * *}$ & $(2.2319)^{* *}$ & $(2.2264)^{* *}$ & $(0.7070)$ \\
\hline \multirow{2}{*}{ Roe } & 1.5223 & 3.9262 & 8.8931 & 1.2963 & 5.0113 & 3.3784 \\
\hline & $(2.2248)^{* *}$ & $(1.6445)^{*}$ & $(2.9617) * * *$ & $(1.6506)^{*}$ & $(2.0419)^{* *}$ & $(1.9940)^{* *}$ \\
\hline \multirow{2}{*}{ Region } & 0.693797 & 1.7153 & 1.0046 & 3.6802 & 2.9908 & 1.3808 \\
\hline & $(1.6161)^{*}$ & $(1.9497)^{*}$ & $(2.0502)^{* *}$ & $(3.7890) * * *$ & $(2.2517)^{* *}$ & $(2.7474)^{* *}$ \\
\hline \multirow{2}{*}{ Constant } & -8.4749 & -80.7704 & 14.4114 & 26.9618 & -20.8620 & -7.4852 \\
\hline & $(-0.6706)$ & $(-0.9779)$ & $(0.9877)$ & (1.3806) & $(-1.7325)^{*}$ & $(-0.9572)$ \\
\hline \multirow{2}{*}{$I M R$} & 3.9124 & 2.9113 & 9.8323 & 4.9954 & 1.1199 & 5.7313 \\
\hline & $(5.9983) * * *$ & $(3.1378) * * *$ & $(4.4313)^{* * * *}$ & $(5.9631) * * *$ & $(3.3135)^{* * * *}$ & $(3.1241)^{* * *}$ \\
\hline S.E. & 2.0243 & 2.2050 & 2.7322 & 3.4890 & 1.6111 & 2.4878 \\
\hline Ad. $R^{2}$ & 0.1882 & 0.9339 & 0.1817 & 0.2202 & 0.9986 & 0.4422 \\
\hline Prob. (F-statistic) & 0.0000 & 0.0000 & 0.0000 & 0.0000 & 0.0000 & 0.0000 \\
\hline
\end{tabular}

Overall, the impact of financing constraints on pollutants emissions exists heterogeneity in industry character and ownership. The increase in pollutant emissions caused by the increase in financing constraints is much higher for companies operating in highly polluting industry than for companies from lightly polluting industry. Financing constraints do not affect the pollutant emissions of state-owned companies but aggravate the pollutant emissions of non-state-owned companies to a large extent. These heterogeneity conclusions imply that from the perspective of reducing emissions, the impacts of financing constraints on companies from highly polluting industries and non-state-owned companies are worth paying more attention to.

\subsection{Financing channel heterogeneity analysis}

This paper further analyzes the influence of different financing channels. Financing channels usually include bank and internal financing. As Chinese commercial banks have promoted green loans and increased green reviews for potential credit companies in recent years, Chinese companies need to consider more their environmental impacts to obtain bank loans (Xing et al., 2020). As the internal financing channel mainly refers to the retained earnings of companies, the relationship between internal financing and pollutant emissions depends more on the company's initiative towards the environment. Based on these considerations, this paper also discusses how financing channels influence the impact of financial constraints on pollutant emissions of companies operating in various industries (Table 5) and different types of company's ownership (Table 6).

As can be seen from Table 5, bank financing can effectively mitigate the impact of financing constraints on companies' pollutant emissions. Specifically, with each $1 \%$ increase in bank financing, the impact of financing constraints on the emissions of industrial wastewater, industrial solid waste and sulfur dioxide produced by the companies operating in highly (lightly) polluting industries decreased by an average of $189.24 \%(13.30 \%), 58.67 \%(5.62 \%)$ and $7.03 \%(0.59 \%)$, respectively. These findings reveal the significant role of bank loan on corporate environmental behavior, which may be because green review in loans of Chinese commercial banks requires potential credit companies to have positive environmental performance when using loan funds (Xing et al., 2020). Moreover, the results also suggest that bank financing has a much greater impact on reducing emissions of the companies from highly polluting industry than reducing emissions of the companies from lightly polluting industry, which is consistent with the findings of existing research. Zhang et al. (2011) found that China's green credit policy has the most apparent impact on the companies operating in industries with high pollution and 
high energy consumption. These results imply that the loans to companies from highly polluting industry play a more important role in reducing pollutant emissions than the loans to companies from lightly polluting industries.

Internal financing can also mitigate the impact of financing constraints on companies' pollutant emissions. Specifically, with each 1\% increase in internal financing, the impact of financing constraints on the emissions of industrial wastewater, industrial solid waste and sulfur dioxide produced by the companies operating in highly polluting industry decreased by an average of $1.69 \%, 2.88 \%$ and $0.04 \%$, respectively. These findings suggest that companies from highly polluting industry are more aware of their environmental impact and take a greater initiative in reducing emissions. Companies operating in highly polluting industries are more willing to use internal financing to reduce pollutant emissions, as consumer preferences for environmentally friendly products and equipment reduce unit product costs (Zhao et al., 2014). Moreover, the statistically insignificant coefficients capturing the impact of internal financing on the pollutant emissions of companies from lightly polluting industry suggest that the increase in internal financing does not affect the environmental behavior of such companies that thus do not take a major initiative in reducing their environmental impact.

Overall, financing channels influence how the pollutant emissions of companies operating in different industries are affected by financing constraints. Compared with internal financing, bank financing plays a greater role in mitigating the impact of financing constraints on companies' pollutant emissions through green loan projects. After obtaining bank loans, the level of emission reduction achieved by the companies from highly polluting industry is significantly higher than that achieved by the companies operating in lightly industry. The policy implications of these findings may be that besides the green loan policy must be implemented and adhered to, the green loan policy needs to be directed mainly at the companies operating in highly polluting industries that have more responsible corporate environmental behavior to maximize the environmental impact of green funds.

How financing channels influence the impact of financial constraints on pollutant emissions of companies with different types of ownership are also tested. As can be seen from Table 6, bank financing can mitigate the impact of financing constraints on companies' pollutant emissions. Specifically, with each 1\% increase in bank financing, the impact of financing constraints on the emissions of industrial wastewater, industrial solid waste and sulfur dioxide produced by the nonstate-owned companies decreased by an average of 3.03\%, $2.97 \%$ and $7.47 \%$, respectively. However, the effects of bank financing on the emissions of industrial wastewater and industrial solid waste produced by the Chinese state-owned companies are not significant. Only in the case of sulfur dioxide emissions, the impact of financing constraints on the state-owned companies' emissions decreased by an average of $0.49 \%$ with each $1 \%$ increase in bank financing. These findings confirm the significant effect of bank financing on corporate environmental behavior and the efforts of companies to reduce their emissions to obtain loans from Chinese commercial banks (Xing et al., 2020). The level of emission reductions achieved by non-state-owned companies is significantly higher than that of state-owned companies, as non-state-owned companies must make greater efforts to obtain bank loans, while state-owned companies that obtain loans relatively easily do not need to make additional efforts in emission reduction (Brandt and Li, 2003; Allen et al., 2005).

Internal financing cannot effectively mitigate the impact of financing constraints on companies' pollutant emissions as the statistically insignificant coefficients capturing the impact of internal financing on the pollutant emissions of state-owned and non-state-owned companies suggest. Only in the case of sulfur dioxide emissions, the impact of financing constraints on the non-state-owned companies' emissions decreased by an average of $0.05 \%$ with each $1 \%$ increase in internal financing. These results imply that both state-owned and non-state-owned companies are not proactive in reducing emissions as they are reluctant to use internal financing to improve their environmental performance. 
Table 5.

Results of the sample selection bias corrected model capturing the impact of financing constraints on pollutant emissions of companies operating in different industries considering the effects of bank and internal financing channels. $T$-values are reported in parentheses. The symbols *,**, and *** indicate significance at the $10 \%, 5 \%$, and $1 \%$ levels, respectively.

\begin{tabular}{|c|c|c|c|c|c|c|c|c|c|c|c|c|}
\hline & \multicolumn{6}{|c|}{ Bank financing channel } & \multicolumn{6}{|c|}{ Internal financing channel } \\
\hline & \multicolumn{3}{|c|}{ Highly Polluting Industry } & \multicolumn{3}{|c|}{ Lightly Polluting Industry } & \multicolumn{3}{|c|}{ Highly Polluting Industry } & \multicolumn{3}{|c|}{ Lightly Polluting Industry } \\
\hline & (13) & (14) & (15) & (16) & (17) & (18) & (19) & (20) & (21) & (22) & (23) & (24) \\
\hline & $\ln w a t e r$ & lnsolid & $\ln \mathrm{SO}_{2}$ & $\ln w a t e r$ & lnsolid & $\ln \mathrm{SO}_{2}$ & lnwater & lnsolid & $\ln \mathrm{SO}_{2}$ & lnwater & lnsolid & $\ln \mathrm{SO}_{2}$ \\
\hline$F C$ & $\begin{array}{c}17.1824 \\
(9.8755) * * *\end{array}$ & $\begin{array}{c}2.3462 \\
(6.7776)^{* * *}\end{array}$ & $\begin{array}{c}2.0513 \\
(2.0642)^{* *}\end{array}$ & $\begin{array}{c}5.0450 \\
(1.8486)^{*}\end{array}$ & $\begin{array}{c}2.6751 \\
(3.1750) * * *\end{array}$ & $\begin{array}{c}3.6413 \\
(1.1151)\end{array}$ & $\begin{array}{c}12.3167 \\
(4.8938) * * *\end{array}$ & $\begin{array}{c}4.6775 \\
(4.1124) * * *\end{array}$ & $\begin{array}{c}1.5425 \\
(3.2138)^{* * *}\end{array}$ & $\begin{array}{c}4.1124 \\
(1.6400)^{*}\end{array}$ & $\begin{array}{c}3.4495 \\
(1.8943)^{*}\end{array}$ & $\begin{array}{c}2.8741 \\
(2.2883)^{* * *}\end{array}$ \\
\hline$F C^{*}$ Bank & $\begin{array}{c}-189.2407 \\
(-11.829)^{* * *}\end{array}$ & $\begin{array}{c}-58.6654 \\
(-7.8453)^{* * *}\end{array}$ & $\begin{array}{c}-7.0254 \\
(-2.4154)^{* *}\end{array}$ & $\begin{array}{l}-13.3060 \\
(1.8593)^{*}\end{array}$ & $\begin{array}{c}-5.6209 \\
(-3.1290)^{* * *}\end{array}$ & $\begin{array}{c}-0.5912 \\
(4.0538)^{* * *}\end{array}$ & & & & & & \\
\hline$F C *$ Internal & & & & & & & $\begin{array}{c}-1.6894 \\
(-4.3059)^{* * * *}\end{array}$ & $\begin{array}{c}-2.8813 \\
(-3.6753)^{* *}\end{array}$ & $\begin{array}{c}-0.0413 \\
(-1.9625)^{* *}\end{array}$ & $\begin{array}{c}-148.8413 \\
(-1.0766)\end{array}$ & $\begin{array}{c}244.2646 \\
(1.0015)\end{array}$ & $\begin{array}{c}-43.061 \\
(-0.5687)\end{array}$ \\
\hline Size & $\begin{array}{c}4.5994 \\
(3.2117) * * *\end{array}$ & $\begin{array}{c}4.4327 \\
(2.9898) * * *\end{array}$ & $\begin{array}{c}6.3529 \\
(3.3235)^{* * *}\end{array}$ & $\begin{array}{c}-3.9107 \\
(-1.1582)\end{array}$ & $\begin{array}{c}6.7887 \\
(1.9612) * *\end{array}$ & $\begin{array}{c}0.6718 \\
(0.1748)\end{array}$ & $\begin{array}{c}5.9813 \\
(2.9122)^{* * *}\end{array}$ & $\begin{array}{c}2.1623 \\
(3.4512)^{* * * *}\end{array}$ & $\begin{array}{c}6.4023 \\
(5.2892) * * *\end{array}$ & $\begin{array}{l}-4.8674 \\
(-1.500)\end{array}$ & $\begin{array}{c}7.4402 \\
(1.2100)\end{array}$ & $\begin{array}{c}4.4714 \\
(1.6947)^{*}\end{array}$ \\
\hline$S i z e^{2}$ & $\begin{array}{c}-0.2067 \\
(-2.9673)^{* * * *}\end{array}$ & $\begin{array}{c}-0.2517 \\
(-2.7765)^{* * * *}\end{array}$ & $\begin{array}{c}-0.2585 \\
(-2.9063)^{* * *}\end{array}$ & $\begin{array}{c}0.1945 \\
(1.1409)\end{array}$ & $\begin{array}{c}-0.2887 \\
(-1.7486)^{*}\end{array}$ & $\begin{array}{c}-0.0456 \\
(-2.2367)^{* *}\end{array}$ & $\begin{array}{c}-0.2756 \\
(-2.6726)^{* *}\end{array}$ & $\begin{array}{c}-0.2114 \\
(-2.1892)^{* *}\end{array}$ & $\begin{array}{c}-0.2595 \\
(-4.4701)^{* * *}\end{array}$ & $\begin{array}{c}0.2418 \\
(1.6279)^{*}\end{array}$ & $\begin{array}{c}-0.3400 \\
(-1.6018)^{*}\end{array}$ & $\begin{array}{c}-0.2021 \\
(-1.6857)^{*}\end{array}$ \\
\hline Age & $\begin{array}{c}0.2148 \\
(0.7469)\end{array}$ & $\begin{array}{c}-0.1005 \\
(-3.1115)^{* * * *}\end{array}$ & $\begin{array}{c}-0.0926 \\
(-3.3014)^{* * *}\end{array}$ & $\begin{array}{c}0.0858 \\
(1.7242)^{*}\end{array}$ & $\begin{array}{c}-0.3019 \\
(-2.1649)^{* *}\end{array}$ & $\begin{array}{c}0.1566 \\
(2.1763)^{* *}\end{array}$ & $\begin{array}{c}-0.2413 \\
(-4.7093)^{* * * *}\end{array}$ & $\begin{array}{c}-0.1264 \\
(-3.4721)^{* * *}\end{array}$ & $\begin{array}{c}-0.0874 \\
(-3.6309)^{* * *}\end{array}$ & $\begin{array}{c}0.0848 \\
(1.5759)\end{array}$ & $\begin{array}{c}-0.1448 \\
(-1.8117)^{*}\end{array}$ & $\begin{array}{c}0.0893 \\
(1.6346)^{*}\end{array}$ \\
\hline Roe & $\begin{array}{c}-2.6531 \\
(-3.8002)^{* * * *}\end{array}$ & $\begin{array}{c}-5.1224 \\
(-3.5543)^{* * * *}\end{array}$ & $\begin{array}{c}-6.7217 \\
(-3.3175)^{* * *}\end{array}$ & $\begin{array}{c}8.3426 \\
(1.7935)^{*}\end{array}$ & $\begin{array}{c}1.6293 \\
(1.6564)^{*}\end{array}$ & $\begin{array}{c}-2.3782 \\
(-1.9029)^{*}\end{array}$ & $\begin{array}{c}-3.3022 \\
(-4.5618)^{* * * *}\end{array}$ & $\begin{array}{c}-4.3173 \\
(-1.9321)^{*}\end{array}$ & $\begin{array}{c}-5.3253 \\
(-2.8458)^{* *}\end{array}$ & $\begin{array}{c}1.0272 \\
(1.9738)^{*}\end{array}$ & $\begin{array}{c}2.8342 \\
(1.6744)^{*}\end{array}$ & $\begin{array}{c}2.2153 \\
(2.5574)^{* *}\end{array}$ \\
\hline Region & $\begin{array}{c}-0.5180 \\
(-1.7621)^{*}\end{array}$ & $\begin{array}{l}-1.2167 \\
(-1.908)^{*}\end{array}$ & $\begin{array}{c}-0.6800 \\
(-2.2707)^{* *}\end{array}$ & $\begin{array}{c}5.2438 \\
(6.6274)^{* * *}\end{array}$ & $\begin{array}{c}3.5999 \\
(3.1891)^{* * * *}\end{array}$ & $\begin{array}{c}-0.7930 \\
(-0.7850)\end{array}$ & $\begin{array}{c}-0.9435 \\
(-1.8671)^{*}\end{array}$ & $\begin{array}{c}-0.8443 \\
(-2.8519)^{* *}\end{array}$ & $\begin{array}{c}-0.7622 \\
(-2.7468)^{* *}\end{array}$ & $\begin{array}{c}4.4327 \\
(6.2351)^{* * *}\end{array}$ & $\begin{array}{c}3.3395 \\
(3.3199)^{* * *}\end{array}$ & $\begin{array}{c}0.9728 \\
(1.6639)^{*}\end{array}$ \\
\hline Constant & $\begin{array}{c}-14.4157 \\
(-2.0245)^{* *}\end{array}$ & $\begin{array}{c}-50.0067 \\
(-2.1890)^{* *}\end{array}$ & $\begin{array}{c}-28.0384 \\
(-2.7573)^{* *}\end{array}$ & $\begin{array}{l}26.2201 \\
(1.5875)\end{array}$ & $\begin{array}{c}-24.10623 \\
(-0.7860)\end{array}$ & $\begin{array}{c}6.3623 \\
(0.3295)\end{array}$ & $\begin{array}{c}-21.4256 \\
(-2.0918)^{* *}\end{array}$ & $\begin{array}{c}-11.7352 \\
(2.0081)^{* *}\end{array}$ & $\begin{array}{c}-28.5992 \\
(-4.5860) * * *\end{array}$ & $\begin{array}{c}31.8154 \\
(2.0841)^{* *}\end{array}$ & $\begin{array}{l}-28.6652 \\
(-1.0289)\end{array}$ & $\begin{array}{c}-16.411 \\
(-1.2586)\end{array}$ \\
\hline$I M R$ & $\begin{array}{c}2.7324 \\
(4.8642)^{* * *}\end{array}$ & $\begin{array}{c}2.7513 \\
(4.3572)^{* * *}\end{array}$ & $\begin{array}{c}5.5363 \\
(3.8314)^{* * * *}\end{array}$ & $\begin{array}{c}3.2424 \\
(4.7523)^{* * *}\end{array}$ & $\begin{array}{c}3.5341 \\
(3.9623)^{* * *}\end{array}$ & $\begin{array}{c}2.6442 \\
(3.7246)^{* * *}\end{array}$ & $\begin{array}{c}3.6423 \\
(4.1362)^{* * *}\end{array}$ & $\begin{array}{c}4.7413 \\
(5.6324)^{* * *}\end{array}$ & $\begin{array}{c}4.4223 \\
(3.9124)^{* * *}\end{array}$ & $\begin{array}{c}4.7554 \\
(5.3413)^{* * *}\end{array}$ & $\begin{array}{c}3.1317 \\
(5.4316)^{* * *}\end{array}$ & $\begin{array}{c}3.6472 \\
(5.4261)^{* * *}\end{array}$ \\
\hline S.E. & 1.9349 & 1.8790 & 1.9100 & 2.8504 & 1.5364 & 2.8926 & 2.0819 & 1.8988 & 1.8988 & 2.8082 & 1.8353 & 3.1960 \\
\hline Ad. $R^{2}$ & 0.8447 & 0.5467 & 0.4386 & 0.5109 & 0.5838 & 0.3675 & 0.5630 & 0.5496 & 0.5496 & 0.4496 & 0.5122 & 0.4457 \\
\hline Prob. ( $F$-statistic) & 0.0000 & 0.0000 & 0.0000 & 0.0000 & 0.0000 & 0.0000 & 0.0000 & 0.0000 & 0.0000 & 0.0000 & 0.0000 & 0.0000 \\
\hline
\end{tabular}


Table 6.

Results of the sample selection bias corrected model capturing the impact of financing constraints on pollutant emissions of companies with different types of ownership considering the effects of bank and internal financing channels. $t$-values are reported in parentheses. The symbols *,**, and *** indicate significance at the $10 \%, 5 \%$, and $1 \%$ levels, respectively.

\begin{tabular}{|c|c|c|c|c|c|c|c|c|c|c|c|c|}
\hline & \multicolumn{6}{|c|}{ Bank financing channel } & \multicolumn{6}{|c|}{ Internal financing channel } \\
\hline & \multicolumn{3}{|c|}{ State-owned } & \multicolumn{3}{|c|}{ Non-State-owned } & \multicolumn{3}{|c|}{ State-owned } & \multicolumn{3}{|c|}{ Non-State-owned } \\
\hline & (25) & (26) & (27) & (28) & (29) & (30) & $(31)$ & (32) & (33) & (34) & (35) & (36) \\
\hline & $\ln w a t e r$ & lnsolid & $\ln \mathrm{SO}_{2}$ & lnwater & lnsolid & $\ln \mathrm{SO}_{2}$ & lnwater & lnsolid & $\ln \mathrm{SO}_{2}$ & lnwater & lnsolid & $\ln \mathrm{SO}_{2}$ \\
\hline$F C$ & $\begin{array}{c}4.0361 \\
(1.8149)^{*}\end{array}$ & $\begin{array}{c}0.2689 \\
(1.9281)^{* *}\end{array}$ & $\begin{array}{c}6.5289 \\
(2.7224) * *\end{array}$ & $\begin{array}{c}0.2469 \\
(2.2229) * *\end{array}$ & $\begin{array}{c}21.7485 \\
(5.8695)^{* * * *}\end{array}$ & $\begin{array}{c}2.5861 \\
(2.5157)^{* *}\end{array}$ & $\begin{array}{c}3.5982 \\
(1.7351)^{*}\end{array}$ & $\begin{array}{c}0.3543 \\
(6.2779)^{* * * *}\end{array}$ & $\begin{array}{c}1.8134 \\
(1.6849)^{*}\end{array}$ & $\begin{array}{c}0.1403 \\
(2.1286)^{* *}\end{array}$ & $\begin{array}{c}16.5830 \\
(1.7351)^{*}\end{array}$ & $\begin{array}{c}2.1982 \\
(1.9486)^{* *}\end{array}$ \\
\hline$F C *$ Bank & $\begin{array}{c}5.8534 \\
(0.9275)\end{array}$ & $\begin{array}{l}15.4605 \\
(1.0848)\end{array}$ & $\begin{array}{c}-0.4931 \\
(-5.3693)^{* * * *}\end{array}$ & $\begin{array}{c}-3.0274 \\
(2.0493) * *\end{array}$ & $\begin{array}{c}-2.9705 \\
(-1.8277)^{*}\end{array}$ & $\begin{array}{c}-7.4737 \\
(-2.4763)^{* *}\end{array}$ & & & & & & \\
\hline$F C *$ Internal & & & & & & & $\begin{array}{l}26.4976 \\
-0.8424)\end{array}$ & $\begin{array}{c}5.8083 \\
(0.2922)\end{array}$ & $\begin{array}{l}-10.6011 \\
(-0.3790)\end{array}$ & $\begin{array}{l}-15.1614 \\
(-0.4311)\end{array}$ & $\begin{array}{l}-24.2414 \\
(-0.7856)\end{array}$ & $\begin{array}{c}-0.0539 \\
(-1.7196)^{*}\end{array}$ \\
\hline Size & $\begin{array}{c}-0.0343 \\
(-0.0124)\end{array}$ & $\begin{array}{c}1.0342 \\
(0.2406)\end{array}$ & $\begin{array}{c}-0.2918 \\
(-0.2322)\end{array}$ & $\begin{array}{c}0.0797 \\
(0.0286)\end{array}$ & $\begin{array}{c}2.5688 \\
(0.7989)\end{array}$ & $\begin{array}{c}1.0613 \\
(0.8761)\end{array}$ & $\begin{array}{c}0.0421 \\
(0.0167)\end{array}$ & $\begin{array}{c}6.1158 \\
(10.7057) * * *\end{array}$ & $\begin{array}{c}2.2631 \\
(2.0545)^{* *}\end{array}$ & $\begin{array}{c}0.7574 \\
(0.3140)\end{array}$ & $\begin{array}{c}4.4928 \\
(1.9594)^{* *}\end{array}$ & $\begin{array}{c}2.6042 \\
(2.4253)^{* *}\end{array}$ \\
\hline$S i z e^{2}$ & $\begin{array}{c}0.0132 \\
(0.0958)\end{array}$ & $\begin{array}{c}-0.0032 \\
(-2.0136)^{* *}\end{array}$ & $\begin{array}{c}0.0344 \\
(1.6040)^{*}\end{array}$ & $\begin{array}{c}0.0078 \\
(2.0566) * *\end{array}$ & $\begin{array}{c}0.0735 \\
(2.4108) * *\end{array}$ & $\begin{array}{c}0.0252 \\
(2.4630)^{* *}\end{array}$ & $\begin{array}{c}0.0124 \\
(0.0978)\end{array}$ & $\begin{array}{c}-0.2834 \\
(-11.2808)^{* * *}\end{array}$ & $\begin{array}{c}-0.0719 \\
(-1.7706)^{*}\end{array}$ & $\begin{array}{c}-0.0251 \\
(-2.2076)^{* *}\end{array}$ & $\begin{array}{c}-0.1941 \\
(-1.7443)^{*}\end{array}$ & $\begin{array}{c}-0.0884 \\
(-1.7311)^{*}\end{array}$ \\
\hline Age & $\begin{array}{c}0.0915 \\
(1.8200)^{*}\end{array}$ & $\begin{array}{c}0.0036 \\
(2.0526)^{* *}\end{array}$ & $\begin{array}{c}0.1543 \\
(4.6612)^{* * * *}\end{array}$ & $\begin{array}{c}0.1073 \\
(2.2987)^{* *}\end{array}$ & $\begin{array}{c}0.1345 \\
(1.9196)^{*}\end{array}$ & $\begin{array}{c}0.1049 \\
(3.1744)^{* * *}\end{array}$ & $\begin{array}{c}0.0760 \\
(1.6264)^{*}\end{array}$ & $\begin{array}{c}0.0497 \\
(1.6999)^{*}\end{array}$ & $\begin{array}{c}0.0863 \\
(2.7249)^{* *}\end{array}$ & $\begin{array}{c}0.0964 \\
(2.2332)^{* *}\end{array}$ & $\begin{array}{c}0.0460 \\
(1.9121)^{*}\end{array}$ & $\begin{array}{c}0.0890 \\
(2.8986) * * *\end{array}$ \\
\hline Roe & $\begin{array}{c}5.6463 \\
(1.6284)^{*}\end{array}$ & $\begin{array}{c}4.7169 \\
(5.4051)^{* * * *}\end{array}$ & $\begin{array}{c}9.8053 \\
(5.3508)^{* * * *}\end{array}$ & $\begin{array}{c}2.6092 \\
(2.3025) * *\end{array}$ & $\begin{array}{c}3.3740 \\
(3.2721)^{* * * *}\end{array}$ & $\begin{array}{c}9.4084 \\
(5.3281)^{* * * *}\end{array}$ & $\begin{array}{c}7.6342 \\
(1.9115)^{* *}\end{array}$ & $\begin{array}{c}3.7024 \\
(5.3736)^{* * * *}\end{array}$ & $\begin{array}{c}6.5342 \\
(3.3565)^{* * * *}\end{array}$ & $\begin{array}{c}5.6821 \\
(1.6969)^{*}\end{array}$ & $\begin{array}{c}4.1135 \\
(8.3024)^{* * * *}\end{array}$ & $\begin{array}{c}7.9931 \\
(3.7728) * * *\end{array}$ \\
\hline Region & $\begin{array}{c}2.7113 \\
(4.1938)^{* * *}\end{array}$ & $\begin{array}{c}2.8889 \\
(4.8626)^{* * *}\end{array}$ & $\begin{array}{c}0.5860 \\
(1.6172)^{*}\end{array}$ & $\begin{array}{c}2.6675 \\
(4.1147)^{* * * *}\end{array}$ & $\begin{array}{c}3.1959 \\
(5.0194)^{* * * *}\end{array}$ & $\begin{array}{c}-0.3727 \\
(-1.0156)\end{array}$ & $\begin{array}{c}2.3157 \\
(3.8693)^{* * *}\end{array}$ & $\begin{array}{c}2.5701 \\
(5.4921)^{* * *}\end{array}$ & $\begin{array}{c}0.7787 \\
(2.1602)^{* *}\end{array}$ & $\begin{array}{c}2.2585 \\
(3.7800)^{* * * *}\end{array}$ & $\begin{array}{c}2.5654 \\
(5.2078)^{* * * *}\end{array}$ & $\begin{array}{c}0.7245 \\
(2.2187)^{* *}\end{array}$ \\
\hline Constant & $\begin{array}{c}7.7098 \\
(0.5711)\end{array}$ & $\begin{array}{c}-1.7299 \\
(-0.0918)\end{array}$ & $\begin{array}{c}7.7213 \\
(1.0957)\end{array}$ & $\begin{array}{c}6.9156 \\
(0.5098)\end{array}$ & $\begin{array}{c}-7.2982 \\
(-0.5009)\end{array}$ & $\begin{array}{c}-0.3266 \\
(-0.0476)\end{array}$ & $\begin{array}{c}7.7920 \\
(0.6362)\end{array}$ & $\begin{array}{c}-24.9051 \\
(-7.7820) * * *\end{array}$ & $\begin{array}{c}-7.8786 \\
(-1.3418)\end{array}$ & $\begin{array}{c}4.1437 \\
(0.3543)\end{array}$ & $\begin{array}{c}17.6110 \\
(1.6095)^{*}\end{array}$ & $\begin{array}{c}9.5827 \\
(1.4043)\end{array}$ \\
\hline$I M R$ & $\begin{array}{c}3.6424 \\
(4.1631)^{* * *}\end{array}$ & $\begin{array}{c}3.4195 \\
(4.3194)^{* * * *}\end{array}$ & $\begin{array}{c}4.2172 \\
(4.1303)^{* * * *}\end{array}$ & $\begin{array}{c}1.3105 \\
(4.1294)^{* * * *}\end{array}$ & $\begin{array}{c}2.4274 \\
(4.1094)^{* * * *}\end{array}$ & $\begin{array}{c}4.9820 \\
(3.1390)^{* * * *}\end{array}$ & $\begin{array}{c}2.4290 \\
(4.4981)^{* * *}\end{array}$ & $\begin{array}{c}5.2383 \\
(4.9891)^{* * *}\end{array}$ & $\begin{array}{c}1.4210 \\
(4.3942)^{* * * *}\end{array}$ & $\begin{array}{c}4.3203 \\
(3.5141)^{* * * *}\end{array}$ & $\begin{array}{c}4.2368 \\
(3.9353)^{* * * *}\end{array}$ & $\begin{array}{c}3.4294 \\
(6.3423) * * *\end{array}$ \\
\hline S.E. & 1.9215 & 1.8424 & 1.9073 & 2.5521 & 1.4213 & 2.7422 & 2.0113 & 1.9452 & 1.8341 & 2.2911 & 1.7452 & 2.9821 \\
\hline Ad. $R^{2}$ & 0.2843 & 0.7887 & 0.3962 & 0.3116 & 0.7637 & 0.3447 & 0.3402 & 0.7390 & 0.3788 & 0.3260 & 0.7391 & 0.3946 \\
\hline Prob. ( F-statistic) & 0.0000 & 0.0000 & 0.0000 & 0.0000 & 0.0000 & 0.0000 & 0.0000 & 0.0000 & 0.0000 & 0.0000 & 0.0000 & 0.0000 \\
\hline
\end{tabular}


Overall, financing channels influence how the pollutant emissions of companies with different types of ownership are affected by financing constraints. Compared with internal financing, bank financing plays a greater role in mitigating the effects of financing constraints on companies' pollutant emissions through green loan projects. After obtaining bank loans, the level of emission reduction achieved by the non-state-owned companies is significantly higher than that achieved by the state-owned companies. These findings imply that from the perspective of reducing pollutant emissions, China's green loan policy has a major impact and loans need to be directed mainly at the non-state-owned companies to maximize the environmental impact of green funds.

\section{Conclusions and policy implications}

The sample selection bias corrected model is constructed to explore the impact of a company's financing constraints on its pollutant emissions. The results of regression analysis suggest that the pollutant emissions are significantly affected by financing constraints, as the companies facing financing difficulties lack funding for operations and investments that would better control pollutant emissions. Moreover, this paper is also the first research to focus on pollutant emissions at the Chinese company-level. The data on emissions of industrial wastewater, industrial solid waste and sulfur dioxide produced by Chinese companies are collected. In addition, the effects of the industry in which a company operates, the type of a company's ownership and the financing channel on the relationship between financing constraints and pollutant emissions are analyzed and the policy implications are derived. The four following conclusions are drawn.

First, the financing constraints of Chinese companies increase their pollutant emissions, including the emissions of industrial wastewater, industrial solid waste and sulfur dioxide.

Second, the impact of financing constraints on pollutants emissions of the Chinese companies is heterogeneous in the industry character and ownership. The increase in pollutant emissions caused by the increase in financing constraints is much higher for companies operating in highly polluting industry than for companies from lightly polluting industry. Financing constraints do not affect the pollutant emissions of Chinese state-owned companies but aggravate the pollutant emissions of nonstate-owned companies to a large extent.

Third, the financing channels influence how pollutant emissions of companies operating in different industries are affected by financing constraints. Compared with internal financing, bank financing plays a greater role in mitigating the impact of financing constraints on companies' pollutant emissions through green loan projects. When a company operating in a highly polluting industry can obtain bank loans, then its pollutant emissions can be significantly more reduced than a company operating in a lightly polluting industry.

Fourth, the financing channels influence how pollutant emissions of companies with different types of ownership are affected by financing constraints. Compared with internal financing, bank financing has a greater mitigating effect on the impact of financing constraints on companies' pollutant emissions. After obtaining bank loans, the level of emission reduction achieved by the non-state-owned companies is significantly higher than that achieved by the state-owned companies.

Based on these analysis results, several policy implications are derived that can help reduce companies' pollutant emissions from the perspective of financing constraints. First, as environmental pollution has become a global issue of widespread concern, the Chinese government has taken various measures to curb pollution, such as environmental regulations, policy subsidies and taxation. The results of this paper reveal that the degree of financing constraints significantly affects the pollutant emissions of Chinese companies. From the perspective of reducing the companies' pollutions emissions, the current problems of financing constraints in Chinese companies are thus worthy of the attention of the Chinese government.

Second, almost all Chinese companies face some degree of financing constraints (Tian and Lin, 2019). Considering the current situation in the Chinese underdeveloped capital market, which type of companies the policy should support to maximize the improvement in environmental performance is worthy of attention. According to the conclusions of this paper, the pollutant emissions of the companies operating in highly polluting industries and non-state-owned companies are more sensitive to a company's financing constraints. When the financing constraints of these 
companies are eased, the reduction in emission can be significant. Hence, from the perspective of reducing pollutant emissions, the policy should focus on easing the financing constraints of the companies from highly polluting industries and non-state-owned companies.

Third, Chinese commercial banks have vigorously promoted green loans in recent years, increased the review of the environmental performance of credit-granting companies, and tightened the restrictions on loan funds used for green projects (Zhang et al., 2011; Xing et al., 2020). This paper confirmed the significant effect of green loan projects and found that after obtaining bank loans, and financing constraints easing of the companies from highly polluting industries can lead to greater improvement in environmental performance. Thus, the green loan policy must be implemented and adhered to, and needs to be directed mainly at the companies from highly polluting industry that have more responsible corporate environmental behavior to maximize the environmental impact of green funds.

Fourth, compared with their non-state-owned counterparts, the state-owned companies generally have a better reputation and better bank-enterprise relations, and therefore have higher chances of obtaining bank loans (Allen et al., 2005; Brandt and Li, 2003). The findings of this paper confirmed that after obtaining bank loans, the level of emission reduction achieved by the non-stateowned companies is significantly higher than that achieved by the state-owned companies. From the perspective of reducing pollutant emissions, it is more appropriate to increase loans to non-stateowned companies to ease their financing constraints. Therefore, the undifferentiated and reasonable loan rules should be established within commercial banks, and Chinese commercial banks should establish new loan rules that would reasonably favor non-state-owned companies to improve environmental protection.

\section{Reference:}

Allen F, Qian J, Qian M. Law, finance, and economic growth in China. Journal of Financial Economics 2005; 77: 57-116.

Andersen DC. Credit Constraints, Technology Upgrading, and the Environment. Working Papers 2015; 3: 283-319.

Andersen DC. Do credit constraints favor dirty production? Theory and plant-level evidence. Journal of Environmental Economics and Management 2017; 84: 189-208.

Brandt L, Li H. Bank discrimination in transition economies: ideology, information, or incentives? Journal of Comparative Economics 2003; 31: 387-413.

Cai X, Zhu B, Zhang H, Li L, Xie M. Can direct environmental regulation promote green technology innovation in heavily polluting industries? Evidence from Chinese listed companies. Science of The Total Environment 2020; 746: 140810.

Ding S, Guariglia A, Knight J. Investment and financing constraints in China: Does working capital management make a difference? Journal of Banking \& Finance 2013; 37: 1490-1507.

Earnhart D, Lizal L. Effects of ownership and financial performance on corporate environmental performance. Journal of Comparative Economics 2006; 34: 111-129.

Fazzari S, Hubbard RG, Petersen BC. Financing Constraints and Corporate Investment. NBER Working Papers 1987.

Fullerton D, Kim S. Environmental investment and policy with distortionary taxes, and endogenous growth. Journal of Environmental Economics and Management 2008; 56: 141-154.

He Z, Shen W, Li Q, Xu S, Zhao B, Long R, et al. Investigating external and internal pressures on corporate environmental behavior in papermaking enterprises of China. Journal of Cleaner Production 2018; 172: 1193-1211.

Heckman J. Sample Selection Bias as a Specification Error. 1979; 1: 153-161.

Higgins AJ, Hajkowicz S, Bui E. A multi-objective model for environmental investment decision making. Computers \& Operations Research 2008; 35: 253-266.

Hoberg G, Maksimovic V. Redefining Financial Constraints: A Text-Based Analysis. The Review of financial studies 2015; 28: 1312-1352.

Hovakimian A, Hovakimian G. Cash Flow Sensitivity of Investment. European Financial Management 2009; 15: 47-65.

Huang Y, Ji Y. How will financial liberalization change the Chinese economy? Lessons from middle- 
income countries. Journal of Asian Economics 2017; 50: $27-45$.

Jiang L, Lin C, Lin P. The determinants of pollution levels: Firm-level evidence from Chinese manufacturing. Journal of Comparative Economics 2014; 42: 118-142.

Li D, Cao C, Zhang L, Chen X, Ren S, Zhao Y. Effects of corporate environmental responsibility on financial performance: The moderating role of government regulation and organizational slack. Journal of Cleaner Production 2017; 166: 1323-1334.

Manova K. Financing constraints, heterogeneous firms, and international. The Review of Economic Studies 2013; 2: 711-744.

Song H, Zhao C, Zeng J. Can environmental management improve financial performance: An empirical study of A-shares listed companies in China. Journal of Cleaner Production 2017; 141: 1051-1056.

Tian P, Lin B. Impact of financing constraints on firm's environmental performance: Evidence from China with survey data. Journal of Cleaner Production 2019; 217: 432-439.

Vinayagamoorthi V, Selvam M, Lingaraja K, Miencha I, Raja M. Testing Environmental Kuznets Curve Hypothesis at Firm Level in India. Journal of Sustainable Development 2016; 8.

Wu H, Guo H, Zhang B, Bu M. Westward movement of new polluting firms in China: Pollution reduction mandates and location choice. Journal of Comparative Economics 2017; 45: 119-138.

Xing C, Zhang Y, Wang Y. Do Banks Value Green Management in China? The Perspective of the Green Credit Policy. Finance Research Letters 2020; 35: 101-601.

$\mathrm{Yu}$ C, Wu X, Zhang D, Chen S, Zhao J. Demand for green finance: Resolving financing constraints on green innovation in China. Energy Policy 2021; 153: 112-255.

Yu S, Gao S, Sun H. A dynamic programming model for environmental investment decision-making in coal mining. Applied Energy 2016; 166: 273-281.

Zhang B, Yang Y, Bi J. Tracking the implementation of green credit policy in China: Top-down perspective and bottom-up reform. Journal of Environmental Management 2011; 92: 1321-1327.

Zhang D, Du W, Zhuge L, Tong Z, Freeman RB. Do financial constraints curb firms' efforts to control pollution? Evidence from Chinese manufacturing firms. Journal of Cleaner Production 2019; 215: 10521058 .

Zhang Y, Xing C, Wang Y. Does green innovation mitigate financing constraints? Evidence from China's private enterprises. Journal of Cleaner Production 2020; 264: 121-698.

Zhao H, Gao Q, Wu Y, Wang Y, Zhu X. What affects green consumer behavior in China? A case study from Qingdao. Journal of Cleaner Production 2014; 63: 143-151.

Zhou X, Tang X, Zhang R. Impact of green finance on economic development and environmental quality: a study based on provincial panel data from China. Environmental Science and Pollution Research 2020; 27: 19915-19932. 